\title{
Effects of breast-feeding compared with formula-feeding on preterm infant body composition: a systematic review and meta-analysis
}

\author{
Pan Huang ${ }^{1} \dagger$ Jianghua Zhou $^{2} \dagger$, Yanan Yin $^{1}$, Wenjuan Jing $^{3}$, Biru Luo $^{1 *}$ and Jiang Wang ${ }^{4}$ \\ ${ }^{1}$ Department of Gynecology and Obstetrics, West China Second University Hospital, Sichuan University, Chengdu 610041, \\ Sichuan, People's Republic of China \\ ${ }^{2}$ Department of the Center of Coordination and Innovation for Aging Care and Health Promotion of Sichuan, Chengdu \\ Medical School, Chengdu 610041, Sichuan, People's Republic of China \\ ${ }^{3}$ Department of Obstetrics, West China Second University Hospital, Sichuan University, Chengdu 610041, Sichuan, People's \\ Republic of China \\ ${ }^{4}$ College of Nursing, Jinggangshan University, Jian 343009, Jiangxi, People's Republic of China
}

(Submitted 7 November 2015 - Final revision received 8 February 2016 - Accepted 30 March 2016 - First published online 16 May 2016 )

\section{Abstract}

We conducted a systematic review and meta-analysis to compare the effect of breast-feeding and formula-feeding on body composition of preterm infants. We searched the literature using PubMed, Cochrane Central Library Issue, Ovid (Medline), Embase and other resources such as Google Scholar, electronic databases and bibliographies of relevant articles; two reviewers collected and extracted data independently. All the authors assessed risk of bias independently using the Newcastle-Ottawa Scale (NOS). A fixed-effects meta-analysis was undertaken with RevMan 5 software (The Cochrane Collaboration) using the inverse variance method ( $P \geq 0 \cdot 05 ; \chi^{2}$ test). In contrast, a random-effects meta-analysis was carried out. Altogether, 630 articles were identified using search strategy, and the references within retrieved articles were also assessed. A total of six studies were included in this systematic review. In formula-fed infants, fat mass was higher at term (mean difference $0 \cdot 24(95 \% \mathrm{CI} 0 \cdot 17,0 \cdot 31) \mathrm{kg}$ ), fat-free mass was higher at 36 weeks of gestational (mean difference $0 \cdot 12(95 \% \mathrm{CI} 0 \cdot 04,0 \cdot 21) \mathrm{kg})$ and the percentage of fat mass was higher at 36 weeks of gestation (mean difference 3.70 (95\% CI 1.81, 5.59) kg) compared with breast-fed infants. Compared with breast-feeding, formula-feeding is associated with altered body composition from birth to term in preterm infants. The effects of formula-feeding on preterm infant body composition from term to 12-month corrected age are inconclusive in our study. Well-designed studies are required in the future to explore the effects of formula-feeding compared with breast-feeding.

Key words: Breast-feeding: Formula-feeding: Preterm infants: Body composition

To achieve optimal growth, preterm infants need better nutrition in the neonatal period than any other time of their life because of decreased intra-uterine nutrient deposition ${ }^{(1)}$. The American Academy of Pediatrics recommends that breast milk should be the preferred feeding for all infants. Formula milk is recommended when human milk supply is inadequate or the mother is unable to breast-feed ${ }^{(2)}$. Meanwhile, preterm infants often require additional supervisions and support systems compared with term infants, because their buccal coordination and swallowing mechanisms are not fully matured ${ }^{(3)}$. In addition, despite lower weight and shorter length than term infants upon discharge, preterm infants have been found to show a catch-up growth and abnormal adiposity at term corrected age, which indicates a potential risk factor for $\mathrm{CVD}^{(4,5)}$. Therefore, it is essential to monitor growth and body composition changes continuously in relation to different nutrition interventions, because growth pattern and body composition appear to have a long-term effect on health outcomes ${ }^{(6)}$.

It is quite clear that a period of rapid growth would be likely to have negative effects on long-term health outcomes ${ }^{(7)}$, and unbalanced catch-up growth of fat mass (FM) could attribute to this association. At the same time, two types of rapid catch-up growth in preterm infants exist ${ }^{(8)}$ : one is paralleled by an increase in 'predominantly FM' and the other by 'predominantly fat-free mass (FFM)'. Moreover, evidence suggests that FFM and FM can also provide precise determinations of body composition $^{(9)}$. Therefore, important implications can be obtained by measuring FM and FFM.

Despite the critical inter-relationship between early nutrition, growth, development, and subsequent health, a few data are

\footnotetext{
Abbreviations: FM, fat mass; FFM, fat-free mass.
}

*Corresponding author: B. Luo, fax +8628 8559065, email hpwthx@163.com

$\dagger$ These authors contributed equally to this work. 
available on changes of body composition in preterm infants during the 1 st year of life. In addition, systematic reviews that determine the effect of formula milk feeding compared with maternal breast milk feeding on rate of growth and developmental outcomes in preterm or low birth weight infants have been inconclusive, because no data from randomised trials of formula milk $v$. maternal breast milk for feeding preterm or low birth weight infants could be obtained ${ }^{(10)}$. Meanwhile, the study of Fewtrell et $a l^{(11)}$ suggested that breast-feeding or high-sn-2 infant formula has no significant effect on bone mass in the long term.

The purpose of our study was to assess the effects of breast-feeding $v$. formula-feeding on body composition by collecting all the evidence available from cohort studies comparing the effects of breast-feeding $v$. formula-feeding on preterm infant body composition.

\section{Methods}

\section{Protocol and registration}

Our systematic review was registered at http://www.crd.york.ac.uk/ PROSPERO/, with the registration number CRD42015023335.

\section{Eligibility criteria}

(1) The participants were preterm infants ( $\leq 37$ weeks of gestation at birth and/or $2500 \mathrm{~g}$ ) without congenital malformations or complications affecting body composition.

(2) The types of exposure were breast-feeding (exclusive or predominant) and formula-feeding (exclusive or predominant). Broadly, formula milk can be considered as follows: (i) 'term' formulae, designed for term infants providing $280-293 \mathrm{~kJ} / 100 \mathrm{ml}(67-70 \mathrm{kcal} / 100 \mathrm{ml})$; (ii) 'preterm' formulae, designed to provide nutrient intakes to match intra-uterine accretion rates with energy enrichment (about $335 \mathrm{~kJ} / 100 \mathrm{ml}(80 \mathrm{kcal} / 100 \mathrm{ml})$ ), variably protein and mineral enrichment ${ }^{(12)}$. The effects of breast-feeding and formula-feeding on body composition were measured at the same time points.

(3) The outcomes were FM (kg), FFM ( kg) and the percentage of FM. We excluded studies in which body composition was measured by skinfold thickness because of its poor ability to predict body composition ${ }^{(13)}$.

(4) The types of studies were cohort studies; no language restrictions were placed. Review articles and commentaries were excluded.

\section{Information sources}

This systematic review was designed and carried out according to the guidelines of the Preferred Reporting Items for Systematic Reviews and Meta-Analyses ${ }^{(14)}$. This included electronic searches of databases such as PubMed (http://www.ncbi.nlm.nih.gov/ pubmed/), Cochrane Central Library Issue, Ovid(medline), Embase and other resources (such as Google Scholar). All databases were searched from their earliest records to May 2015 and were updated in August 2015.
Search

Subject terms, keywords and truncation symbol were used in the search strategy. The search method was adjusted in accordance with each database, using a combination of key words such as (('Premature Birth') OR ('Infant, Premature') OR ('Labor, Premature')) AND (('Infant formulas') OR ('artificial formula') OR ('breast feeding') OR ('human milk')) AND (('body composition') OR ('Body Fat Distribution')), as well as Medical Subject headings (MeSH) terms; for example, ('Breast feeding') AND ('Infant formula') AND ('Infant premature') AND ('Body composition'). The search strategy details are given in the online Supplementary material. References of eligible articles and previous reviews were manually searched for studies probably suitable for inclusion.

\section{Study selection}

We identified relevant studies by examining the titles and abstracts of all studies or by obtaining a full text of the article if no abstract was available. The potentially eligible articles were reassessed by retrieving and evaluating the full text. Screening was conducted independently by two reviewers (P. H. and J. Z.). Inter-reviewer reliability for the study selection process was determined by the Kappa test. The consistency of our study was $61.3 \%$. In case of disagreement for inclusion or exclusion, the issue was discussed until consensus was achieved by the reviewers (P. H. and J. Z.).

\section{Data collection process}

Data were collected by two independent review authors (P. H. and J. W.). Efforts were made to contact authors for additional data if the articles were suitable for a meta-analysis. Authors were asked to provide mean values and standard deviations for primary outcomes including FM, FFM and the percentage of FM. We attempted to send the second request if our first request did not yield a response. The study was excluded from the meta-analyses if the author was unable to provide additional data.

\section{Data items}

The following data were extracted from the included studies: study design, year of publication, location, demographic characteristics of the participants, definition of exposure, measuring technology of body composition, outcome and potential sources of bias.

\section{Risk of bias in individual studies}

All the authors assessed the risk of bias independently using the Newcastle-Ottawa Scale (NOS): (1) representativeness of the exposed cohort, (2) comparability of groups, (3) blinding of investigators who measured outcomes, (4) the time and completeness of follow-up, (5) contamination bias and (6) other potential sources of bias. Articles were scored as follows: $\geq 7=$ high quality (NOS).

\section{Summary measures}

We calculated the mean difference and 95\% CI of outcome at each postnatal age point between the formula-fed and breast-fed groups. 


\section{Synthesis of results}

We performed a meta-analysis on studies that reported the outcomes (FM, FFM and the percentage of FM) between formulafed and breast-fed groups at the following time points: 32-week corrected gestational age, 36-week gestational age, term, 3-month corrected age, 6-month corrected age and 12-month corrected age. We calculated the mean difference and $95 \% \mathrm{CI}$ of outcome at each postnatal age point between the formula-fed and breast-fed groups. The $\chi^{2}$ test for Cochrane's $\mathrm{Q}$ statistic and $I^{2}$ were used to test heterogeneity ${ }^{(15)}$. A fixed-effects meta-analysis was undertaken with RevMan 5 software (The Cochrane Collaboration) by using the inverse variance method ( $P \geq 0.05 ; \chi^{2}$ test). In contrast, a random-effects meta-analysis was carried out. This method was performed separately for each postnatal age point.

\section{Risk of bias across studies}

Publication bias was assessed using funnel plots.

\section{Additional analyses}

We intended to conduct subgroup analyses for sex and the same measuring technique of outcome.

\section{Results}

\section{Study selection and characteristics}

The characteristics of included and excluded studies are outlined in Fig. 1. A total of 630 articles were retrieved by search strategy, and eight articles were additionally identified by assessing the references of the retrieved articles and other sources. In total, 206 articles were removed as they were duplicate records of the same report through reference management software and manual screening. After examination of titles and abstracts, thirty articles were considered relevant; six studies were included and twenty-four studies were excluded after full-text review for the following reasons: the articles included breast-fed infants or formula-fed infants separately ${ }^{(16,17)}$; the primary outcomes were not reported ${ }^{(18-23)}$; the measurement method of body composition was skinfold thickness only ${ }^{(24)}$; articles were reviews ${ }^{(6,25-27)}$; the subjects were not preterm infants ${ }^{(28,29)}$; the language used was not English ${ }^{(30-32)}$; the studies were randomised-controlled trials ${ }^{(33,34)}$; and the studies were conference publications ${ }^{(35-37)}$.

Altogether, six studies were included in this systematic review $^{(38-43)}$ (Table 1 ). We made efforts to contact the authors of three studies because data in their articles for meta-analysis were incomplete ${ }^{(35-37)}$; one author replied but was unable to provide additional data ${ }^{(35)}$, and we therefore excluded the three studies from the meta-analysis. All studies were longitudinal. The main technique used to measure body composition was dual-energy X-ray absorptiometry (DXA) ${ }^{(38,40-43)}$, and the other techniques used included body electrical impedance analysis $^{(39)}$. Measurements of outcomes were conducted at a range of time points from birth to 12-month corrected age (Table 1). Only one study reported whether investigators were blinded when measuring the outcomes ${ }^{(39)}$. The feeding methods were prospectively defined in all studies, although the

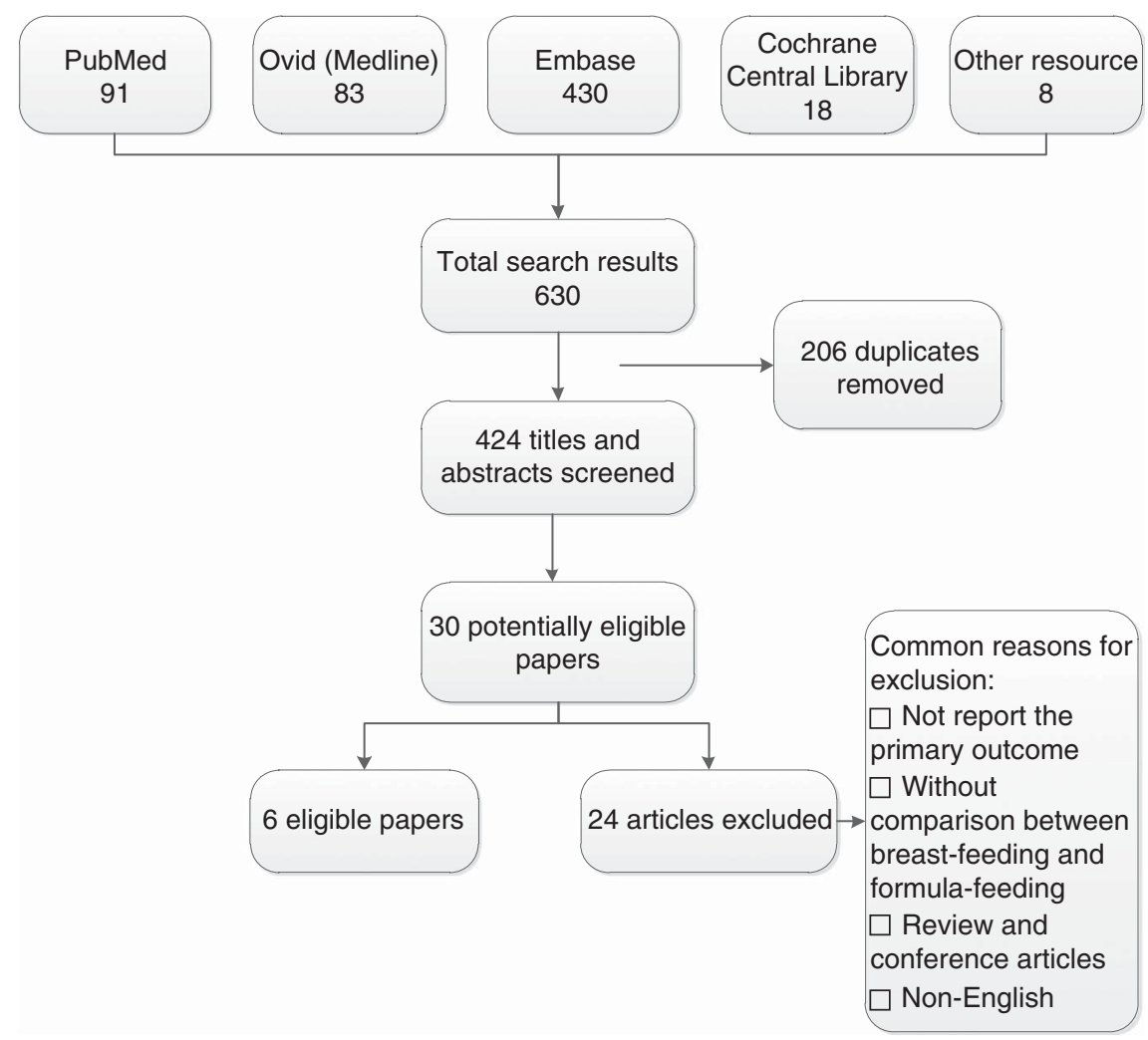

Fig. 1. Flow diagram of the search results. 
Table 1. Characteristics of the six included studies in the systematic review

\begin{tabular}{|c|c|c|c|c|c|c|}
\hline First author, year & $\begin{array}{l}\text { Characteristics of population, } \\
\text { study detail }\end{array}$ & Quality* & $\begin{array}{l}\text { Body-composition technique used, } \\
\text { model used, adjusted for infancy } \\
\text { (yes or no), reference used for adjustment, } \\
\text { blinding assessment (yes or no) }\end{array}$ & $\begin{array}{l}\text { Study groups: } \\
\text { no. of infants }\end{array}$ & $\begin{array}{l}\text { Age at body- } \\
\text { composition } \\
\text { measurement }\end{array}$ & Definitions of breast-feeding and formula-feeding \\
\hline Cooke, $2010^{(38)}$ & $\begin{array}{l}\text { LS, } 164 \text { preterm infants with a GA } \\
\leq 34 \text { weeks and a birth weight } \\
\leqq 1750 \text { g; the subjects have no } \\
\text { systemic disease requiring no } \\
\text { medication and are growing } \\
\text { normally. UK }\end{array}$ & 7 & $\begin{array}{l}\text { DXA, three-compartment model was } \\
\text { used (FM, FFM and bone mass) with } \\
\text { age-specific values }{ }^{(57)} \text {, blinding } \\
\text { not stated }\end{array}$ & $\begin{array}{l}\text { BF: } 25 \\
\text { FF: } 139\end{array}$ & $\begin{array}{l}\text { Term } \\
\text { 3-month CA } \\
\text { 6-month CA } \\
\text { 12-month CA }\end{array}$ & $\begin{array}{l}\text { BF: } 25 \text { preterm infants were assessed prospectively and studied at the } \\
\text { same time } \\
\text { FF: } 56 \text { preterm infants fed with PTF between discharge and } \\
6 \text {-month CA (energy } 335 \mathrm{~kJ} / 100 \mathrm{ml}(80 \mathrm{kcal} / 100 \mathrm{ml}) \text {, protein } \\
2.2 \mathrm{~g} / 100 \mathrm{ml} \text {, protein:energy ratio } 2.75 \mathrm{~g} / 100 \mathrm{ml}) ; 57 \text { preterm infants } \\
\text { fed a TF between discharge and } 6 \text {-month CA (energy } 276 \mathrm{~kJ} / 100 \mathrm{ml} \\
\text { ( } 66 \mathrm{kcal} / 100 \mathrm{ml}) \text {, protein } 1.4 \mathrm{~g} / 100 \mathrm{ml} \text {, protein:energy ratio } \\
2.1 \mathrm{~g} / 100 \mathrm{ml}) ; 26 \text { preterm infants fed PTF between discharge and } \\
\text { term and then the TF between term and } 6 \text {-month CA }\end{array}$ \\
\hline Amesz, $2010^{(43)}$ & $\begin{array}{l}\text { LS, } 152 \text { preterm infants with a GA } \\
\leq 32 \text { weeks or with a birth } \\
\text { weight } \leq 1500 \text { g; one of their } \\
\text { main caretakers spoke Dutch } \\
\text { or English. Amsterdam, } \\
\text { Netherlands }\end{array}$ & 7 & $\begin{array}{l}\text { DXA, two-compartment model, } \\
\text { calculations performed by using } \\
\text { age-specific values }{ }^{(58)} \text {, blinding not stated }\end{array}$ & $\begin{array}{l}\text { BF: } 50 \\
\text { FF: } 50\end{array}$ & $\begin{array}{l}\text { Term } \\
\text { 6-month CA }\end{array}$ & $\begin{array}{l}\text { BF: BM was fortified with standard BM fortifier until term CA. The } \\
\text { predefined exclusively breast-feeding was that at least } 80 \% \text { of the } \\
\text { total milk intake was BM. Infants receiving unfortified BM were } \\
\text { supplemented with } 200 \mathrm{IU}(5 \mu \mathrm{\mu g} \text { ) of vitamin D daily. } 50 \text { infants were } \\
\text { exclusively BF at term age. } 19 \text { of } 50 \text { at } 3 \text {-month CA, } 7 \text { of } 19 \text { at } \\
\text { 3-month CA } \\
\text { FF: at term CA, } 50 \text { infants fed TF (energy } 280 \mathrm{~kJ} / 100 \mathrm{ml}(67 \mathrm{kcal} / 100 \mathrm{ml} \text { ), } \\
\text { protein } 1.47 \mathrm{~g} / 100 \mathrm{ml} \text {, protein:energy ratio } 2 \cdot 19 \mathrm{~g} / 100 \mathrm{ml} \text { ) (Friso } 1 \\
\text { normal; Friesland Foods) }\end{array}$ \\
\hline $\begin{array}{l}\text { Costa-Orvay, } \\
2011^{(39)}\end{array}$ & $\begin{array}{l}\text { LS, } 38 \text { preterm infants with } \\
\text { GA } \leq 32 \text { weeks and } \\
\text { weight } \leqq 1500 \mathrm{~g} \text {; the subjects } \\
\text { were recruited to the } \\
\text { neonatology ward of Hospital } \\
\text { Clinic in Barcelona, Spain. } \\
\text { Barcelona, Spain }\end{array}$ & 6 & 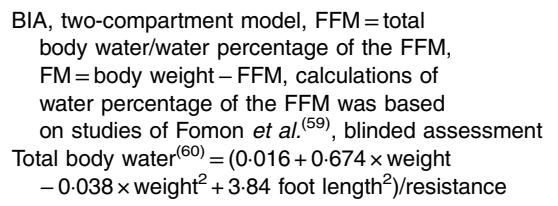 & $\begin{array}{l}\text { BF: } 6 \\
\text { FF: } 8\end{array}$ & $\begin{array}{l}\text { 32-week CGA } \\
\text { 36-week CGA }\end{array}$ & $\begin{array}{l}\text { BF:BM } 160 \mathrm{ml} / \mathrm{kg} \text { per d + Enfamil Human Milk fortifier } 4.5 \mathrm{~g} / \mathrm{kg} \text { per d } \\
\text { FF: PTF, Alprem (Nestle) } 160 \mathrm{ml} / \mathrm{kg} \text { per } \mathrm{d} \text { (in } 100 \mathrm{~g}=2117 \mathrm{~kJ} \text { ( } 506 \mathrm{kcal} \text { ), } \\
\text { protein } 14.5 \mathrm{~g} \text {, carbohydrate } 53.6 \mathrm{~g} \text {, fat } 26.0 \mathrm{~g} \text { ) was given to the FF } \\
\text { group }\end{array}$ \\
\hline Wauben, $1998^{(40)}$ & $\begin{array}{l}\text { LS, } 37 \text { preterm infants. Additional } \\
\text { data obtain from authors. } \\
\text { Hamilton, Ontario, Canada }\end{array}$ & 6 & $\begin{array}{l}\text { DXA, three-compartment model was used } \\
\text { (FM, FFM and BMC) with age-specific values }{ }^{(61)} \text {, } \\
\text { blinding not stated }\end{array}$ & $\begin{array}{l}\text { BF: } 15 \\
\text { FF: } 22\end{array}$ & $\begin{array}{l}\text { Term } \\
\text { 3-month CA } \\
\text { 6-month CA } \\
\text { 12-month CA }\end{array}$ & $\begin{array}{l}\text { BF: the predefined breast-feeding was over } 60 \% \text { of enteral intake as } \\
\text { BM. } 15 \text { infants were fed BM at term age, ten at } 3 \text {-month CA, } 7 \text { at } \\
6 \text {-month CA. Supplemental Fe was provided at approximately } 10 \mathrm{mg} \\
\text { daily up to } 6 \text {-month CA. } 12 \text { preterm infants received a new } \\
\text { multinutrient fortifier and } 12 \text { preterm infants received Ca and P before } \\
\text { hospital discharge } \\
\text { FF: } 22 \text { infants exclusively TF. If infants received Fe-fortified formula, Fe } \\
\text { was provided at approximately } 10 \mathrm{mg} \text { daily up to } 6 \text {-month CA. } 12 \\
\text { infants received special premature infant formula (Preemie SMA, } \\
\text { Wyeth-Ayerst) before hospital discharge } \\
\text { All preterm infants received approximately } 400 \mathrm{IU}(10 \mathrm{\mu g}) \text { supplemental } \\
\text { vitamin D after hospital discharge }\end{array}$ \\
\hline Atkinson, $2000^{(42)}$ & $\begin{array}{l}\text { LS, } 151 \text { preterm infants were } \\
\text { recruited in this study. Ontario, } \\
\text { Canada }\end{array}$ & 6 & $\begin{array}{l}\text { DXA, three-compartment model, calculations } \\
\text { performed by using age-specific values }{ }^{(62)} \\
\text { blinding not stated }\end{array}$ & $\begin{array}{l}\text { BF: } 27 \\
\text { FF: } 34\end{array}$ & Term & $\begin{array}{l}\text { BF: the predefined BM was }>80 \% \text { of total milk intake up to } \\
\text { 3-month CA. Infants fed expressed mother's milk with either added } \\
\text { multinutrient fortifier or Ca and P during hospitalisation } \\
\text { FF: exclusively or predominantly TF. Most infants received a special } \\
\text { premature infant formula (Preemie SMA, Wyeth-Ayerst) while in the } \\
\text { hospital }\end{array}$ \\
\hline Pieltain, $2001^{(41)}$ & $\begin{array}{l}\text { LS, } 54 \text { healthy preterm infants, } \\
\text { birth weight < } 1750 \text { g; Belgium }\end{array}$ & 6 & $\begin{array}{l}\text { DXA, four-compartment model was used (FM, } \\
\text { FFM, BMD and bone mass) with age-specific } \\
\text { values }{ }^{(63)} \text {, blinding not stated }\end{array}$ & $\begin{array}{l}\text { BF: } 20 \\
\text { FF: } 34\end{array}$ & $\begin{array}{l}\text { 32-week CGA } \\
\text { 36-week CGA }\end{array}$ & $\begin{array}{l}\text { BF: BM was supplemented with banked human milk as available and by } \\
\text { up to } 3-4 \% \text { with two similar fortifiers: Eoprotin (Milupa) or BMF } \\
\text { (Nutricia) } \\
\text { FF: the group of FF received PTF Nenatal (Nutricia), Prematil (Milupa) or } \\
\text { Premie (Wyeth) }\end{array}$ \\
\hline
\end{tabular}

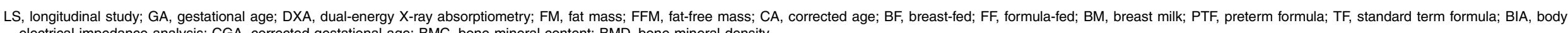

electrical impedance analysis; CGA, corrected gestational age; BMC, bone mineral content; BMD, bone mineral density,
* Quality of the cohort studies were assessed using Newcastle-Ottawa Scale, $\geq 7$ = high quality. 
definitions of feeding group varied (Table 1). FM, FFM and the percentage of FM of the feeding group for each study are shown in Table 2. Variables not normally distributed were not extracted $^{(43)}$.

\section{Risk of bias within studies}

The risk of bias of each study is presented in Table 1 .

\section{Synthesis of results}

Both FFM and percentage of FM in the formula-fed group were significantly higher compared with the breast-fed group at 36-week corrected gestational age. The mean difference of the percentage of FM was $0.20(95 \% \mathrm{CI}-1 \cdot 11,1.51) \mathrm{kg}$ at 32 -week corrected gestational age. No significant mean differences in FM were found between the formula-fed group and the breast-fed group at 32- and 36-week corrected gestational age (Fig. 2-4); two articles ${ }^{(39,41)}$ reported the outcomes at 32- and 36-week corrected gestational age. Percentage of FM was not provided in one study ${ }^{(39)}$ even after we contacted the author; therefore, we excluded this study from the analysis for the percentage of FM. Formula-fed infants had significantly higher FM than breast-fed infants at term. No significant differences were detected in FFM or the percentage of FM (Fig. 2-4). The variables were not normally distributed, and thus the outcomes are not presented as mean values and standard deviations ${ }^{(43)}$. No significant differences were found in FM, FFM or the percentage of FM between the formula-fed and the breast-fed groups at 3-month, 6-month and 12-month corrected age (Fig. 2-4). The mean

Table 2. Body composition data of included studies in the systematic review (Mean values and standard deviations) differences in FM were $-0.05 \quad(95 \%$ CI $-0.28,0.17) \mathrm{kg}$ at 3 -month, $-0.03(95 \% \mathrm{CI}-0.32,0.25) \mathrm{kg}$ at 6 -month, -0.09 (95\% CI $-0.37,0.19) \mathrm{kg}$ at 12 -month corrected age. The mean differences in FFM were $0.24(95 \% \mathrm{CI}-0 \cdot 19,0 \cdot 66) \mathrm{kg}$ at 3 -month and $0.08(95 \% \mathrm{CI}-0.26,0.42) \mathrm{kg}$ at 12 -month corrected age.

\section{Pooled differences}

Fig. 2-4 indicate pooled differences in FM, FFM and the percentage of FM between the formula-fed and breast-fed infants by postnatal 1 year of corrected age.

\section{Risk of bias across studies}

The funnel plots of studies at 32- and 36-week gestational age indicated no considerable publication bias.

\section{Discussion}

\section{Summary of evidence}

On the basis of the current available evidence from six studies with data available from 642 infants, we found significant complex differences in body composition between breastfeeding and formula-feeding on preterm infants at 1 year of corrected age. The outcomes of the meta-analysis indicated that formula-fed infants had higher FM at 32-week corrected gestational age, 36-week corrected gestational age and term. By 3-month corrected age, this difference was no longer

\begin{tabular}{|c|c|c|c|c|c|c|c|c|c|c|c|c|c|}
\hline \multirow{3}{*}{$\begin{array}{l}\text { First author, year (reference), } \\
\text { study groups: no. of infants }\end{array}$} & \multirow[b]{3}{*}{ Age } & \multicolumn{4}{|c|}{ Fat mass } & \multicolumn{4}{|c|}{ Fat-free mass } & \multicolumn{4}{|c|}{ Percentage of fat mass } \\
\hline & & \multicolumn{2}{|c|}{ BF } & \multicolumn{2}{|c|}{ FF } & \multicolumn{2}{|c|}{$\mathrm{BF}$} & \multicolumn{2}{|c|}{$\mathrm{FF}$} & \multicolumn{2}{|c|}{$\mathrm{BF}$} & \multicolumn{2}{|c|}{$\mathrm{FF}$} \\
\hline & & Mean & SD & Mean & SD & Mean & SD & Mean & SD & Mean & SD & Mean & SD \\
\hline \multicolumn{14}{|l|}{ Cooke, $2010^{(38)}$} \\
\hline BF: 25 & Term & 0.331 & 0.128 & 0.570 & 0.22 & $2 \cdot 171$ & 0.296 & 2.669 & 0.400 & 13 & 3.2 & $17 \cdot 3$ & $5 \cdot 3$ \\
\hline FF: 139 & 3-month CA & 1.365 & 0.527 & $1 \cdot 310$ & 0.4 & 3.762 & 1.051 & 3.998 & 0.417 & 25 & $8 \cdot 2$ & $24 \cdot 3$ & $5 \cdot 1$ \\
\hline & 6-month CA & 1.934 & 0.658 & 1.900 & 0.6 & 5.063 & 0.568 & 5.088 & 0.522 & 27 & $6 \cdot 8$ & $26 \cdot 7$ & $5 \cdot 7$ \\
\hline \multicolumn{14}{|l|}{ Amesz, $2010^{(43)}$} \\
\hline BF: 50 & Term & - & & - & & 2.95 & 0.55 & 3.05 & 0.42 & - & & - & \\
\hline $\begin{array}{l}\text { FF: } 50 \\
\text { Cosat-Orvay, } 2011^{(39)}\end{array}$ & 6-month CA & - & & - & & 4.91 & 0.75 & $5 \cdot 64$ & 0.62 & $32 \cdot 1$ & $9 \cdot 1$ & $26 \cdot 8$ & $6 \cdot 2$ \\
\hline $\mathrm{BF}: 6$ & 32-week CGA & 0.111 & 0.062 & 0.140 & 0.072 & $1 \cdot 190$ & 0.204 & 1.311 & 0.158 & - & & - & \\
\hline $\begin{array}{l}\text { FF: } 8 \\
\text { Wauben, } 1998^{(40)}\end{array}$ & 36-week CGA & 0.202 & 0.049 & 0.193 & 0.049 & 1.699 & 0.206 & 1.773 & 0.152 & - & & - & \\
\hline BF: 15 & Term & - & & - & & - & & - & & $22 \cdot 0$ & 3.0 & $19 \cdot 6$ & 5.4 \\
\hline FF: 22 & 3-month CA & - & & - & & - & & - & & $30 \cdot 1$ & $6 \cdot 4$ & 25.5 & 8.8 \\
\hline & 6-month CA & - & & - & & - & & - & & $27 \cdot 9$ & $4 \cdot 8$ & $28 \cdot 4$ & $8 \cdot 1$ \\
\hline & 12-month CA & - & & - & & - & & - & & 23.9 & $4 \cdot 8$ & 23.9 & $5 \cdot 6$ \\
\hline \multicolumn{14}{|l|}{ Pieltain, $2001^{(41)}$} \\
\hline BF: 20 & 32-week CGA & 0.071 & 0.035 & 0.075 & 0.055 & 1.391 & 0.147 & 1.355 & 0.147 & $4 \cdot 7$ & $2 \cdot 3$ & 4.9 & 2.5 \\
\hline $\begin{array}{l}\text { FF: } 34 \\
\text { Atkinson, } 2000^{(42)}\end{array}$ & 36-week CGA & 0.20 & 0.054 & 0.315 & 0.122 & 1.883 & 0.161 & $2 \cdot 015$ & 0.190 & 9.5 & $2 \cdot 6$ & $13 \cdot 2$ & 4.5 \\
\hline $\begin{array}{l}\text { BF: } 27 \\
\text { FF: } 34\end{array}$ & Term & - & & - & & - & & - & & 22 & 6 & 19 & 5 \\
\hline
\end{tabular}

$\mathrm{BF}$, breast-fed; FF, formula-fed; CA, corrected age; CGA, corrected gestational age. 
Feeding method and infant body composition

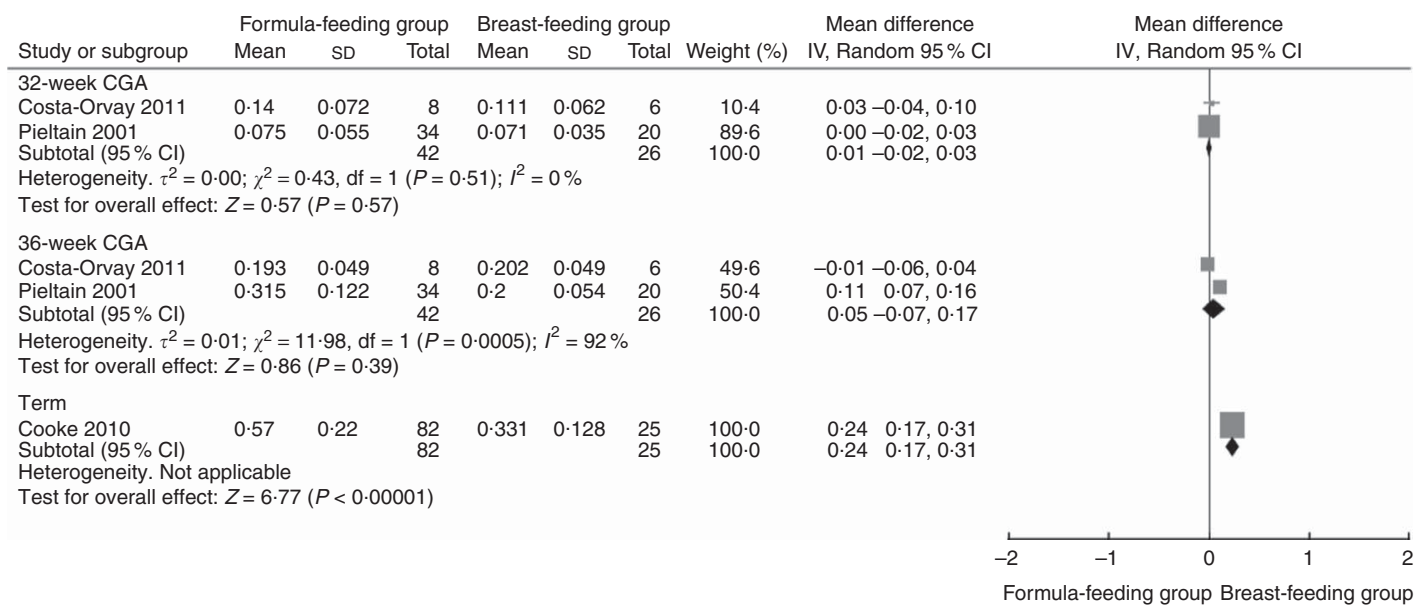

Fig. 2. Pooled mean differences in fat mass between the formula-fed group and the breast-fed group. CGA, corrected gestational age.

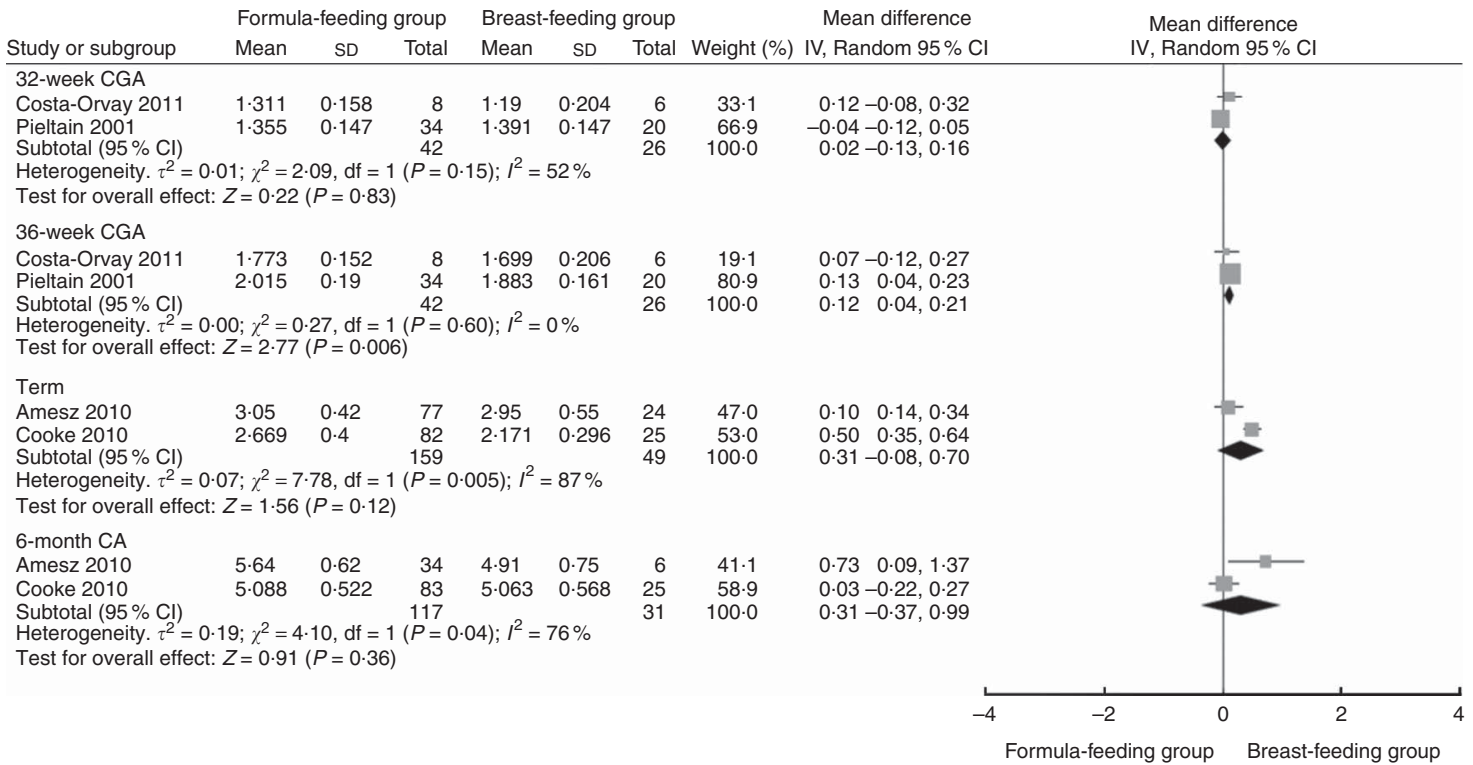

Fig. 3. Pooled mean differences in fat-free mass between the formula-fed group and the breast-fed group. CGA, corrected gestational age; CA, corrected age.

apparent, with a reverse trend and lower FM in formula-fed infants. Formula-fed infants had lower FFM than their breast-fed counterparts at 32-week corrected gestational age but higher FFM from 36-week corrected gestational age to 12-month corrected age. These findings are biologically plausible. Preterm infants were fed preterm formula before term. Preterm formula contains higher levels of protein and energy than term formula. At the initial stages of enteral feeding with high energy intakes ${ }^{(44)}$, rapid weight gain reflects an increase in $\mathrm{FM}^{(45)}$, which is followed by an increase in muscle mass later. Meanwhile, because the ratio of protein:energy in the diet will influence body composition ${ }^{(46)}$, the lower protein:energy ratio of breast milk may lead to less FFM deposition with excess energy deposited as fat. For this reason, the lower protein intake in breast-fed infants may explain the observed higher FM compared with formula-fed infants after term.

Our observed differences in body composition between formula-fed infants and breast-fed infants are inconsistent with the results of the meta-analysis comparing the effects of breast milk on body composition with formula-feeding in healthy, term infants ${ }^{(47)}$. The reasons may be that preterm infants have fewer nutrient reserves at birth than full-term infants, and are often fed preterm formula or supplementation of mother's milk with human milk fortifiers. Moreover, owing to immature metabolic pathways for nutrient utilisation and/or an immature growth hormone/insulin-like growth factor axis, the absorption and assimilation of nutrients are limited. Meanwhile, although late preterm infants (gestational age between 34 and 36 weeks) are usually able to breast-feed, they are more likely to experience difficulty in establishing successful breast-feeding than term infants because preterm infants' oro-buccal coordination and swallowing mechanisms may not be fully matured $^{(48)}$. Furthermore, a systematic review was conducted by Arenz et $a l .^{(49)}$, which analysed the association of breast-feeding with childhood obesity. Although the results showed that breast-feeding reduced the risk of obesity in 


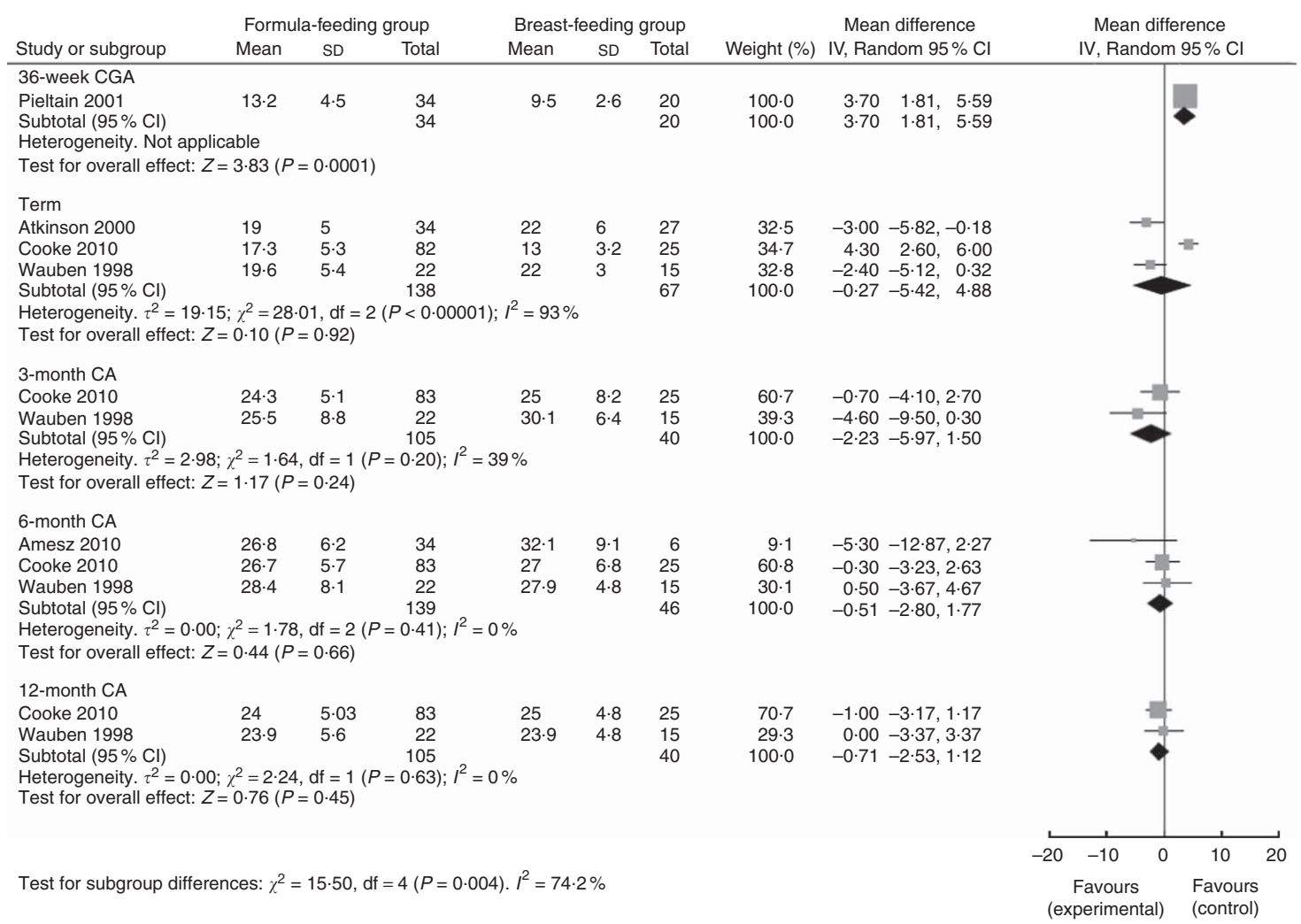

Fig. 4. Pooled mean differences in the percentage of fat mass between the formula-fed group and the breast-fed group. CGA, corrected gestational age; CA, corrected age.

childhood significantly, results from another systematic review carried out by Owen et al. ${ }^{(50)}$ investigating the relation between breast-feeding and BMI throughout life suggested that mean BMI was lower among breast-fed infants, but the difference was small. Promotion of breast-feeding was not likely to reduce mean BMI. The outcome of our meta-analysis indicated that breast-fed infants had lower FM at 32-week corrected gestational age, 36-week corrected gestational age and term compared with formula-fed infants. By 3-month corrected age, this effect was no longer apparent, with a trend towards reversal and higher FM in breast-fed infants. Several drawbacks limited the validity of the meta-analyses, including the types of studies, publication bias, confounding factors and potential heterogeneity between studies.

Some evidences support our outcomes. Investigators have reported that formula-fed infants having higher protein:energy ratio had a higher absolute FFM and lower percentage of $\mathrm{FM}^{(51)}$. Koo \& Hockman ${ }^{(17)}$ found that absolute FFM and FM were increased in infants fed standard formula. Furthermore, in the study of Cooke et $a l .{ }^{(52)}$, absolute FFM and FM were higher in the group of infants fed energy- and protein-enriched formulae, but the percentage of FM did not differ.

DXA is used to evaluate the composition of growth in a single scan. It is non-invasive and of low health risk to the infant, and has therefore been widely used in our included studies. We performed subgroup analyses of studies in which values were measured using this technique. This result supports our analysis of outcomes obtained using different in vivo measurement techniques of body composition.

\section{Limitations}

Our study has several limitations. First, the percentage of FM depends on FFM; therefore, it has been recommended to adjust FM and FFM for height to create independent measures ${ }^{(53)}$ (fat-free mass index (FFMI) and fat mass index (FMI)). However, we could not collect data on FFMI or FMI because of lack of data in included articles. Second, as suggested by Cooke et al. ${ }^{(52)}$, sex was an additional significant independent variable, resulting in an increase in FM and bone mineral content in female infants ${ }^{(54)}$. Nevertheless, we were unable to examine the effect of sex because only a limited number of studies reported outcomes by sex.

Third, breast-feeding was assessed prospectively in all included studies, which limited the recall bias. However, the definition of feeding groups varied widely, and none of the studies used WHO criteria for exclusive breast-feeding, which indicates that a contamination bias may represent an important source of heterogeneity. Moreover, one article did not report the exact definition. Fourth, the infant formulae contained higher levels of long-chain PUFA (LCPUFA), Ca and P. Although the study of de Jong et al. ${ }^{(55)}$ suggested that LCPUFA supplementation does not alter neurological function, no data were available on its effect on body composition. Fifth, one study exploring the association between psychosocial risk factors and 
breast-feeding discontinuation suggested that maternal depression can lead to early discontinuation of breast-feeding ${ }^{(56)}$. Meanwhile, women who choose formula-feeding often lack confidence in their ability to breast-feed, because they think formula may be better for their infants or their milk is inadequately supplied. Therefore, the body compositions were probably affected by psychosocial factors. Finally, none of the included articles mentioned the blinding of data collectors $^{(38-43)}$.

\section{Conclusion}

In summary, this systematic review suggests that formulafeeding is associated with altered body composition from delivery to term in preterm infants compared with breastfeeding. The effects of formula-feeding on preterm infant body composition from term to 1 year of corrected age are inconclusive. Our findings enable to confirm the possible contributions of breast-feeding and formula-feeding on risk of obesity in childhood and adult life.

The number of studies included in our analysis is limited, and the findings from our meta-analysis should be confirmed by future studies. Meanwhile, well-designed studies are required to define the effect of formula-feeding on body composition compared with breast-feeding.

\section{Acknowledgements}

The authors thank Guan-jian Liu from Evidence-Based Medicine Center of China for his assistance in data analysis. The authors also thank Qiu-ui Hao from West China Hospital of Sichuan University and Dong-tao Lin from College of Foreign Languages and Cultures of Sichuan University for editing the manuscript.

This research received no specific grant from any funding agency, commercial or not-for-profit sectors.

B. L. assisted P. H. and J. Z. in formulating the research questions and supervising the quality of this manuscript. Designing the study and screening of the articles were conducted by two reviewers (P. H. and J. Z.). P. H. and J. W. collected data. J. Z. and Y. Y. analysed the data. P. H. and J. Z. wrote the article, and $\mathrm{J}$. W. revised the article.

None of the authors has any conflicts of interest to declare.

\section{Supplementary material}

For supplementary material/s referred to in this article, please visit http://dx.doi.org/doi:10.1017/S0007114516001720

\section{References}

1. Hay WW Jr, Lucas A, Heird WC, et al. (1999) Workshop summary: nutrition of the extremely low birth weight infant. Pediatrics 104, 1360-1368.

2. Eidelman AI, Schanler RJ, Johnston M, et al. (2012) Breastfeeding and the use of human milk. Am Acad Pediatrics 129, e828-e841.

3. Wang ML, Dorer DJ, Fleming MP, et al. (2004) Clinical outcomes of near-term infants. Pediatrics 114, 372-376.
4. Roggero P, Giannì ML, Amato O, et al. (2009) Is term newborn body composition being achieved postnatally in preterm infants? Early Hum Dev 85, 349-352.

5. Uthaya S, Thomas EL, Hamilton G, et al. (2005) Altered adiposity after extremely preterm birth. Pediatr Res 57, 211-215.

6. Roggero P, Giannì ML, Piemontese $\mathrm{P}$, et al. (2012) Effect of nutrition on growth and body composition in infants born preterm. J Matern Fetal Neonatal Med 25, 49-52.

7. Sighal A \& Lucas A (2004) Early origins of cardiovascular disease: is there a unifying hypothesis? Lancet 363, 1642-1645.

8. Ong KK (2007) Catch-up growth in small for gestational age babies: good or bad? Curr Opin Endocrinol Diabetes Obes 14, 30-34.

9. Mazess RB, Barden HS, Bisek JP, et al. (1990) Dual-energy $\mathrm{x}$-ray absorptiometry for total-body and regional bone mineral and soft-tissue composition. Am J Clin Nutr 51, 1106-1112.

10. Henderson G, Anthony MY \& McGuire W (2007) Formula milk versus maternal breast milk for feeding preterm or low birth weight infants. The Cochrane Database Systematic Reviews 2007, issue 17, CD002972. http://onlinelibrary.wiley. com/doi/10.1002/14651858.CD002972.pub2/full

11. Fewtrell MS, Kennedy K, Murgatroyd PR, et al. (2013) Breastfeeding and formula feeding in healthy term infants and bone health at age 10 years. BrJ Nutr 110, 1061-1067.

12. Fewtrell M \& Lucas A (1999) Nutritional physiology: dietary requirements of term and preterm infants. Textbook of Neonatology, 3rd ed., pp. 305-325 [JM Rennie and NRC Roberton, editors]. Edinburgh: Churchill Livingstone.

13. de Bruin NC, van Velthoven KA, Stijnen T, et al. (1995) Body fat and fat-free mass in infants: new and classic anthropometric indexes and prediction equations compared with total body electrical conductivity. Am J Clin Nutr 61, 1195-1205.

14. Moher D, Liberati A, Tetzlaff J, et al. (2009) Preferred reporting items for systematic reviews and meta-analyses: the PRISMA statement. BMJ 339, b2535.

15. Higgins JP \& Thompson SG (2002) Quantifying heterogeneity in a meta analysis. Stat Med 21, 1539-1558.

16. Aimone A, Rovet J, Ward W, et al. (2009) Growth and body composition of human milk-fed premature infants provided with extra energy and nutrients early after hospital discharge: 1-year follow-up. J Pediatr Gastroenterol Nutr 49, 456-466.

17. Koo WW \& Hockman EM (2006) Posthospital discharge feeding for preterm infants: effects of standard compared with enriched milk formula on growth, bone mass, and body composition. Am J Clin Nutr 84, 1357-1364.

18. Kagan BM, Stanincova V, Felix NS, et al. (1972) Body composition of premature infants: relation to nutrition. Am J Clin Nutr 25, 1153-1164.

19. Forbes GB (1983) Fetal growth and body composition: implications for the premature infant. J Pediatr Gastroenterol Nutr 2, S52-S58.

20. Haschke F, Haiden N, Detzel P, et al. (2013) Feeding patterns during the first 2 years and health outcome. Ann Nutr Metab 62, 16-25.

21. van de Lagemaat M, Rotteveel J, van Weissenbruch MM, et al. (2013) Increased gain in bone mineral content of preterm infants fed an isocaloric, protein-, and mineral-enriched postdischarge formula. Eur J Nutr 52, 1781-1785.

22. Goswami I, Rochow N, Fusch G, et al. (2014) Fat and fat-free mass indices for preterm and term infants during first 6 month of life. Annual Meeting of the Society for Neonatology and Pediatrics Intensive Care, GNPI 2014, Bonn, Germany, 26 June 2014.

23. Goswami I, Rochow N, Fusch G, et al. (2014) Fat mass (FM) and fat free mass (FFM) indices in preterm and term infants during first 6 months of life. Arch Dis Child 99, A395(2). 
24. Dewey KG, Hawck MG, Brown KH, et al. (2005) Infant weight-for-length is positively associated with subsequent linear growth across four different populations. Matern Child Nutr 1, 11-20.

25. Greer FR (2007) Post-discharge nutrition: what does the evidence support? Semin Perinatol 31, 89-95.

26. Corpeleijn WE \& van Goudoever JB (2010) Early nutrient supply and the preterm infant. J Pediatr Gastroenterol Nutr 3, S141-S142.

27. Juretic E \& Guszak V (2014) Nutritional management of preterm infants. Paediatr Croat 58, 221-227.

28. de Zegher F, Sebastiani G, Diaz M, et al. (2012) Body composition and circulating high-molecular-weight adiponectin and IGF-I in infants born small for gestational age: Breast- versus formula-feeding. Diabetes 61, 1969-1973.

29. Butte NF, Wong WW, Hopkinson JM, et al. (2000) Infant feeding mode affects early growth and body composition. Pediatrics 106, 1355-1366.

30. Zamrazilová H, Hainer V, Cerná M, et al. (2007) Influence of early postnatal nutrition in preterm infants on their anthropometric and hormonal characteristics at the age of 10 years. Cas Lek Cesk 146, 278-283.

31. Baranov AA, Namazova-Baranova LS, Beliaeva IA, et al. (2013) Evaluation of premature infants nutritional status by air plethysmography: first Russian prospective study. Vestn Ross Akad Med Nauk 4, 10-16.

32. Beliaeva IA, Namazova-Baranova LS, Tarzian ÉO, et al. (2014) Peculiarities of physical growth and body composition of preterm infants, received different types of feeding, at the discharge from hospital. Vestn Ross Akad Med Nauk 5-6, 71-80.

33. Zachariassen G (2013) Nutrition, growth, and allergic diseases among very preterm infants after hospital discharge. Dan Med $J$ 60, B4588.

34. Ryumina I, Baibarina EN, Grosheva EN, et al. (2013) Air-displacement plethysmography for body composition measurements and growth assessment of infants. 11th World Congress of Perinatal Medicine, Russian Federation, Moscow, 2013.

35. Pludowski P, Czech-Kowalska J, Gruszfeld D, et al. (2009) Positives and negatives of breastfeeding versus formulaProspective evaluation of body composition changes in preterm infants. Bone $\mathbf{4 5}$, S97.

36. Belyaeva I, Skvortsova V, Tarzyan E, et al. (2013) The role of human milk in the prevention of the later obesity in preterm infants. 11th World Congress of Perinatal Medicine, Russian Federation, Moscow, 2013.

37. Belyaeva I, Tarzyan E \& Skvortsova V Growth and body composition in pretern infants at the hospital discharge. 24th European Congress of Perinatal Medicine, Florence, 7 June 2014.

38. Cooke RJ, Griffin IJ \& McCormick K (2010) Adiposity is not altered in preterm infants fed with a nutrient-enriched formula after hospital discharge. Pediatr Res 67, 660-664.

39. Costa-Orvay JA, Figueras-Aloy J, Romera G, et al. (2011) The effects of varying protein and energy intakes on the growth and body composition of very low birth weight infants. Nutr J 10, 140 .

40. Wauben IP, Atkinson SA, Shah JK, et al. (1998) Growth and body composition of preterm infants: influence of nutrient fortification of mother's milk in hospital and breastfeeding post-hospital discharge. Acta Paediatr 87, 780-785.

41. Pieltain C, De Curtis M, Gérard P, et al. (2001) Weight gain composition in preterm infants with dual energy x-ray absorptiometry. Pediatr Res 49, 120-124.
42. Atkinson SA \& Randall-Simpson J (2000) Factors influencing body composition of premature infants at term-adjusted age. Ann N Y Acad Sci 904, 393-399.

43. Amesz EM, Schaafsma A, Cranendonk A, et al. (2010) Optimal growth and lower fat mass in preterm infants fed a proteinenriched postdischarge formula. J Pediatr Gastroenterol Nutr 50, 200-207.

44 Ashworth A (1969) Growth rates in children recovering from protein-calorie malnutrition. Br J Nutr 23, 835-845.

45. MacLean WC Jr \& Graham GG (1980) The effect of energy intake on nitrogen content of weight gained by recovering malnourished infants. Am J Clin Nutr 33 , 903-909.

46. Wauben I, Westerterp K, Gerver W-J, et al. (1995) Effect of varying protein intake on energy balance, protein balance and estimated weight gain composition in premature infants. EurJ Clin Nutr 49, 11-16.

47. Gale C, Logan KM, Santhakumaran S, et al. (2012) Effect of breastfeeding compared with formula feeding on infant body composition: a systematic review and meta-analysis. Am J Clin Nutr 95, 656-669.

48. Engle WA, Tomashek KM, Wallman C, et al. (2007) 'Late-preterm' infants: a population at risk. Pediatrics 120, 1390-1401.

49. Arenz S, Rückerl R, Koletzko B, et al. (2004) Breast-feeding and childhood obesity - a systematic review. Int J Obes Relat Metab Disord 28, 1247-1256.

50. Owen CG, Martin RM, Whincup PH, et al. (2005) The effect of breastfeeding on mean body mass index throughout life: a quantitative review of published and unpublished observational evidence. Am J Clin Nutr 821, 298-1307.

51. Brunton JA, Saigal S \& Atkinson SA (1998) Growth and body composition in infants with bronchopulmonary dysplasia up to 3 months corrected age: a randomized trial of a high-energy nutrient-enriched formula fed after hospital discharge. J Pediatr 133, 340-345.

52. Cooke RJ, McCormick K, Griffin IJ, et al. (1999) Feeding preterm infants after hospital discharge:effect of diet on body composition. Pediatr Res 46, 461-464.

53. VanItallie TB, Yang MU, Heymsfield SB, et al. (1990) Height-normalized indices of the body's fat-free mass and fat mass:potentially useful indicators of nutritional status. $A m \mathrm{~J}$ Clin Nutr 52, 953-959.

54. Pieltain C, De Curtis M, Studinski F, et al. (1999) Gender influence on body composition in preterm infants fed human milk or preterm formula. Pediatr Res 45, 913.

55. de Jong C, Kikkert HK, Fidler V, et al. (2010) The Groningen LCPUFA study: no effect of postnatal long-chain polyunsaturated fatty acids in healthy term infants on neurological condition at 9 years. Br J Nutr 104, 566-572.

56. Taveras EM, Capra AM, Braveman PA, et al. (2003) Clinician support and psychosocial risk factors associated with breastfeeding discontinuation. Pediatrics 112, 108-115.

57. Cooke RJ, Rawling DJ, McCormick K, et al. (1999) Body composition of preterm infants during infancy. Arch Dis Child Fetal Neonatal Ed 80, 188-191.

58. Hammami M, Koo WW \& Hockman EM (2003) Body composition of neonates from fan beam dual energy X-ray absorptiometry measurement. JPEN J Parenter Enteral Nutr 27, 423-426.

59. Fomon SJ, Haschke F, Ziegler EE, et al. (1982) Body composition of reference children from birth to age 10 years. Am J Clin Nutr 35, S1169-S1175.

60. Tang W, Ridout D \& Medi N (1997) Assessment of total body water using bioelectrical impedance analysis in neonates receiving intensive care. Arch Dis Child Fetal Neonatal Ed 77, F123-F126. 
61. Wauben IPM, Atkinson SA, Grad TL, et al. (1998) Moderate nutrient supplementation to mother's milk for premature infants supports adequate bone mineralization and short-term growth: a randomized controlled trial. Am J Clin Nutr 67, 465-472.

62. Brunton JA, Weiler HA \& Atkinson SA (1997) Improvement in the accuracy of dual energy X-ray absorptiometry for whole body and regional analysis of body composition: validation using piglets and methodological considerations in infants. Pediatr Res 41, 590-596.

63. Rigo J, Nyamugabo K, Picaud JC, et al. (1998) Reference values of body composition obtained by dual energy x-ray absorptiometry in preterm and term neonates. I Pediatr Gastroenterol Nutr 27, 184-190. 